\title{
Reference Desk Dilemmas
}

The Impact of

New Demands on Librarianship

\author{
Marcella Knibbe-Haanstra, \\ Guest Columnist
}

Correspondence concerning this column should be addressed to Diane

Zabel, Schreyer Business Library, The

Pennsy/vania State University, 309

Paterno Library, University Park, PA

16802; e-mail:dxz2@psu.edu.

Marcella Knibbe-Haanstra is a master's degree student enrolled in the Library and Information Science program at The University of Western Ontario in London, Ontario.
This guest-authored column, from the perspective of a student who is new to the profession, focuses on stress factors related to reference librarianship and includes suggestions for managing the demands of new technologies, the growing expectations of users, and myriad responsibilities.-Editor

\section{$\mathbf{T}$}

he concept of change has become a thoroughly familiar theme in librarianship. The knowledge that the purpose and position of a librarian is constantly evolving has become more of an accepted phenomenon than it was even ten years ago. This acceptance, however, could be considered an internal knowledge recognized only by those within the profession itself. The external population appears to have a more difficult time acknowledging the steady advancement of librarianship. To the general public, the most popular perception of a librarian might consist of a bespectacled elderly woman who is short-tempered and dresses in ill-fitting clothes. On the opposite end of the spectrum is the objectified female who, thanks to Carmen Electra, is labeled as the "naughty librarian" and can be identified by her plunging neckline and schoolgirl skirt.

Due to ancient stereotypes and commercialized sex, the general public often has a poor perception of a librarian's actual job. According to Les Kranz's Jobs Rated Almanac, piano tuners and file clerks are employed in a more stressful environment than librarians, allowing librarianship to be a comparatively undemanding and stress-free occupation. ${ }^{1}$ Contrary to the perceptions established by this job-ranking list, the modern librarian is expected to be up-to-date on the latest technological developments, information sources, and service management. Librarians have come a long way in the last decade and have learned to embrace change in order to meet patrons' needs. As technology advances and expectations increase, so too must a librarian's abilities, but it is becoming evident that this acceptance of change does not come without its share of stress and potential burnout on the job. A buildup of stress can produce eventual dissatisfaction at work, and this can often lead to negative physical and emotional health, tardiness, absenteeism, and turnover, and may eventually result in complete burnout. ${ }^{2}$ Although workplace stress and burnout are not synonymous, the fact that burnout is a consequence of chronic stress is an indication that being susceptible to the one (unless managed) is an eventual path to the other.

Workplace stress is hardly limited to the library profession. Many other public service-oriented occupations, such as those in the healthcare, childcare, and teaching fields, 


\section{A B C $\cong$ C L I O}

\section{NEW AND FORTHCOMING TITLES}

\section{For Your History Reference Collection}

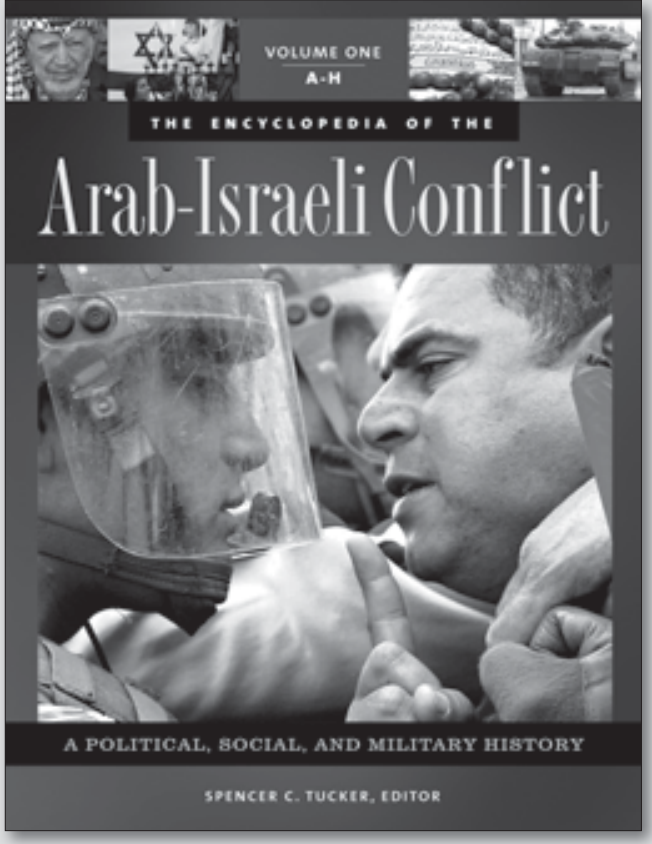

\section{The Encyclopedia of the Arab-Israeli Conflict: A Political, Social, and Military History}

4 Volumes

Spencer C. Tucker, Editor

Priscilla Mary Roberts, Editor, Documents Volume

This exhaustive work offers readers at multiple levels key insights into the military, political, social, cultural, and religious origins of the Arab-Israeli conflict.

May 2008, 1,553 pp., 8.5x11, EAN 978-1-85109-841-5, $\$ 395.00$ eBook is available. Call for pricing.

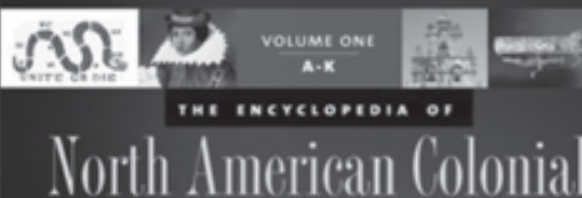
Conflicts to 1775

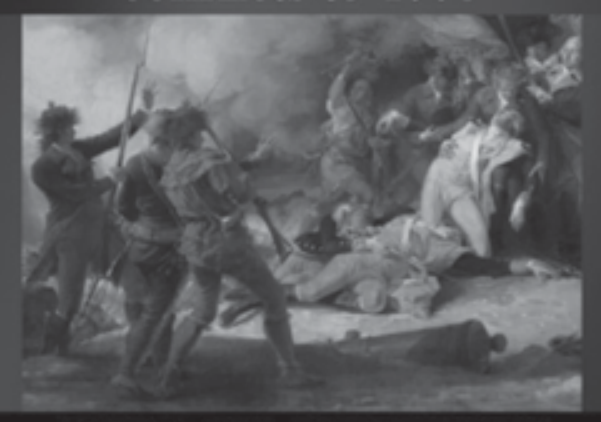

A POLITICAL, SOCLAL, AND MILITARY HISTORY

\section{The Encyclopedia of North American} Colonial Conflicts to 1775:

\section{A Political, Social, and Military History}

3 Volumes

Spencer C. Tucker, Editor

James Arnold and Roberta Wiener, Documents Editors

The only multivolume encyclopedia covering all aspects of North American colonial warfare, with special attention paid to the social, political, cultural, and economic affairs that were affected by the conflicts.

August 2008, 1,077 pp., 8.5x11, EAN 978-1-85109-752-4, \$295.00 eBook is available. Call for pricing. 


\section{FOR YOUR ENRICHMENT}

often experience the same feelings of stress for many of the same reasons. Clients in these professions do not often communicate gratitude to professionals who are trying to help them and will sometimes communicate quite the opposite attitude, creating a hostile and unappreciative environment. Recent studies, however, have found that causes for workplace stress begin at a much more foundational level. A study of mental healthcare workers found that stress resulted from poor leadership, lack of staff autonomy, and an incongruent vision of job objectives. ${ }^{3}$ Experienced teachers blame stress on growing workloads and responsibilities as well as a general lack of support from both the administration and the community. Similarly, social workers are often stressed by societal expectations, an excessive workload, inadequate resources, and a degree of disconnect between themselves and their supervisors. ${ }^{5}$ It is evident that although there is no single definitive cause and therefore no one solution, the reasons contributing to a stressful environment hold distinctive similarities throughout the public service sector, including librarianship.

Although the matter of stress for reference librarians, particularly in the areas of technology, user expectations, and personal responsibilities, is addressed throughout the literature, there is no definite consensus determining the extent to which this stress exists. But there is compelling agreement throughout most of the literature about the remedy for this potentially demanding occupation, regardless of its stress levels.

\section{THE DEMANDS OF NEW TECHNOLOGY}

One of the most important professional competencies established by a RUSA task force is to maintain responsiveness to the user community and to regularly conduct environmental scans of the current developments in library services in order to provide relevant and useful information to patrons. ${ }^{6}$ During the mid-twentieth century, however, the ability to be aware of current sources and services was both limited in scope and simplistic in nature. Janes writes that the majority of literature from that era deals with defining the sources and materials as well as establishing and operating reference services. ${ }^{7}$ During that time, reference librarianship was focused on inventing reference services rather than expanding it to new and diverse forms. Since the 1970s, however, reference librarians have been challenged to create new and innovative ways to improve reference services. For the most part, this includes the construction and maintenance of a library's website, blogs, and wikis, as well as an advanced knowledge in online communication such as e-mail, chat reference, and even virtual worlds such as Second Life. The literature records the many ways reference librarians have responded to these advances in technology, ranging from acceptance and integration to confusion and rejection. ${ }^{8}$ These developments in relation to stressful behavior was named "technostress" by Brod in the early 1980s and defined as "a modern disease of adaptation caused by an inability to cope with the new computer technologies in a healthy manner." "In light of this definition,
Kupersmith identified four particular components of technostress. These components consist of performance anxiety, information overload, role conflicts of professional identity, and burnout. ${ }^{10}$ Ennis explored this concept further by studying the evolution of technostress over a ten-year period. She concluded that stress levels in relation to technology were similar to those from a decade before in terms of an increasing workload and the pace of technological change but also found that, although some difficulties still exist, librarians are now able to manage their stress in a positive manner. ${ }^{11}$

The growing use of the Internet has issued its own effects on librarianship as well. In 2000, Curry and Harris reported that many librarians were still wary of the Internet and its many features due to its disorganized format and countless unreliable sources. ${ }^{12}$ The latest job satisfaction survey carried out by Library Journal in 2007, however, found that the number of librarians who find technology intimidating has plunged 50 percent in the last thirteen years. ${ }^{13}$ Although librarians of an earlier generation are still adapting to new technology and are not adjusting to its changes as quickly, there are also reports that librarians are providing better service with the help of technology. ${ }^{14}$

Although there is growing acceptance of new technologies in librarianship, Van Fleet and Wallace add that the declining numbers of face-to-face reference encounters are affecting librarians in terms of the loss of personal identity, indicating that a number of librarians only communicate through a computer. ${ }^{15}$ This can create a very distant and essentially nonexistent relationship, leaving some librarians with an unfulfilled sense of accomplishment. Cardina and Wicks acknowledge that the emergence of electronic reference has been one of the biggest changes that librarianship has experienced. ${ }^{16}$ However, they perceive the change as an evolving reality that has been developing slowly over the last two decades, which has allowed librarians time to improve their knowledge alongside this growing trend.

The observations of Placzek are in disagreement with this notion of continual technological education. She writes that the learning curve expectations are very high and many reference librarians are often required to teach patrons how to use a resource not long after being first introduced to it. ${ }^{17}$ Chan and Auster agree by noting that a librarian's heavy workload often poses a short time limit on a librarian learning the concepts of new technology or resources. ${ }^{18}$ Although the Internet offers a wealth of training information online, Ennis points out that the opportunity to improve technological skills is hardly useful if a librarian has no time to complete them. ${ }^{19}$

To some reference librarians, it would appear that technology is adding to the workload rather than alleviating it, which is contradictory to its original intent. In addition, although none of the literature condemns technology's introduction as a negative infliction on reference services, there is an understanding that the expectations of "too much, too soon" can seriously upset a librarian's self-assurance of resource awareness. The overwhelming nature of technology 
can, at times, leave librarians feeling frustrated and helpless in the face of constant change and therefore generate a high level of stress.

\section{USER EXPECTATIONS}

Among the many changes occurring within reference librarianship, a proverbial shift in focus has also occurred. Rather than concentrating on internal matters such as collection development and the physical structure of libraries, the library as an institution has shifted its focus toward providing a user-centered service. ${ }^{20}$ Presently, the object and motivation of a reference librarian's work is concentrated on meeting the users' needs and expectations. Although this appears to be a noble cause in itself, the intricacies of such an occupation are extensive and diverse. Caputo goes as far as to state that reference librarians in particular are at the highest risk of total burnout. ${ }^{21}$ Due to their central location within the library and a growing encouragement for interaction between librarians and patrons, reference librarians have to deal with users' expectations for instant information where the patronage can be very numerous and their questions varied in scope..$^{22}$

The majority of students entering post-secondary education today are classified as "Millennials" and have grown up in a multitasking environment complete with immediate feedback and high expectations. ${ }^{23}$ Whether it is through instant coffee or instant messaging, their expectations have changed from "as soon as possible" to simply "now," and this includes answers from the reference desk. In 1987, Bunge conducted a survey of librarians and found that 41.4 percent of the public service librarians surveyed named patrons as a primary cause of stress, with one participant commenting, "patrons expect miracles." ${ }^{24}$ Malamud and Rosenstein observed in 1991 that a 25 percent increase in the workload at the reference desk for one biomedical library was one of the main causes of stress. ${ }^{25}$ A report by Van Fleet and Wallace states that since virtual reference is now available 24/7, users will expect the same availability from other forms of reference offered by the library. ${ }^{26}$ Furthermore, Ennis points out that "user expectations of what is and is not possible and what librarians could and could not do remain[s] a source of frustration." ${ }^{27}$ Although librarianship is often perceived as a simple and uncomplicated occupation, the expectations from users are often beyond a librarian's daily capabilities. As a result, the knowledge that he or she is not living up to users' expectations could potentially bring on feelings of guilt or stress.

Another form of stress in relation to user expectations can occur when a reference librarian is obligated to answer questions that are outside of his or her scope of knowledge. Morris-Knower exemplifies this situation through his own experiences working in a science library with a strong educational background in the humanities. ${ }^{28}$ In these circumstances, both the patron and the librarian might become aggravated by either the lack of knowledge or of consideration, resulting in a stressful situation for both parties. Reenstjerna, however, explicitly denies the idea that user expectations are a base for the fundamental problems of stress in reference service and names them "superficial." 29 Instead, he blames the limits of the traditional paradigm imposed on the library. Despite this somewhat absolute perspective, many studies have acknowledged the fact that user expectations have been climbing, with patrons counting on round-the-clock reference service and instantaneous answers. With that premise in place and a relatively limited budget for additional staff, reference librarians are liable to experience many stressful situations where expectations surmount their knowledge capabilities.

\section{A GROWING NUMBER OF RESPONSIBILITIES}

It could be argued that the main cause of stress for reference librarians is the ever-increasing number of responsibilities alongside a declining period of time for personal and professional development. A study conducted by Cardina and Wicks found that the jobs performed by reference librarians in a ten-year period had grown from 10.65 to 14.07 and that the time spent on professional development had been cut almost in half, plummeting down to 6 percent from 13 percent..$^{30}$ Reference librarians are no longer simply responsible for answering questions and locating books. They are expected to instruct, reach out, teach, promote, and advertise alongside their traditional duties. ${ }^{31}$ Extra duties that have been mentioned ranged from as blasé as minding a bookstore to unrelated positions such as being an audiovisual assistant. Placzek points out that there are also many additional activities carried out by a reference librarian that could be considered obligatory but are difficult to define, such as creating informative handouts or subject guides and lending students a sympathetic ear. She writes, "Being a reference librarian is sort of like being a bartender without the sticky beer mess and the drunks." ${ }^{32}$ There are additional tasks for a reference librarian to undertake that are time consuming but are difficult to identify and record. As Butcher points out, "librarians are overworked. It's not as if they have too much to do, but rather that they are pulled in too many directions." ${ }^{33}$ Financial restrictions and budget cuts are often to blame for these additional tasks, and although funds are declining, the escalating expectations of the patron must be met.

With new responsibilities constantly being added to the list, it is assumed that measures are being taken to encourage professional development. But a study by Chan and Auster indicates that, for many libraries, the absence of a policy on this issue disables anyone, save a lucky few, from receiving further training. ${ }^{34}$ Altogether, the combination of escalating responsibilities and inadequate training points toward a potentially stressful position for reference librarians to occupy. Placzek fully places the blame on a crammed schedule and associates stress and burnout with a librarian's realization of the insufficient amount of time to carry out these duties. ${ }^{35}$

On the other hand, Cardina and Wicks found no correlation between the number of jobs performed and the level of job satisfaction, indicating that perhaps the increasingly busy 


\section{FOR YOUR ENRICHMENT}

nature of the job has no affect on the stress levels of reference librarians. ${ }^{36}$ Ennis appears to support this perspective by reporting that 83 percent of the librarians in her survey felt positive about the future of reference librarianship despite the increasing workload. ${ }^{37}$ Therefore it appears that although reference librarians are steadily adding to their schedule, they are embracing the challenges that these changes are creating, thus proving the resourcefulness and passion that many librarians display through their work.

\section{STRESS MANAGEMENT}

Even though there is disagreement in the literature about the central cause of stress for reference librarians, the fact that all of the writing discusses remedial solutions to potential stress indicates that it does, in fact, exist. The literature offers the following three remedies to stress in reference librarianship: personal time management and development, coworker cooperation, and upper management support. Placzek is a strong supporter of organization and time management to help alleviate stress and also suggests that a sense of humor and an open perspective create a more stress-free environment in the workplace. ${ }^{38}$ Ennis as well as Chan and Auster advise reference librarians to take time for training and outside instruction. ${ }^{39}$ Spires recommends that all librarians take a moment to step outside of the library during the work day and take a breath of fresh air. ${ }^{40}$ Finally, Landry suggests that librarians cultivate an interesting and enjoyable life outside of work. ${ }^{41}$

In terms of relationships within the staff itself, Ennis recommends a support system between coworkers in order to realize that other staff members share the burden, which will help manage stress. ${ }^{42}$ Spires highlights colleagues as one of the most valuable resources available, and Quinn suggests that reference librarians engage in positive reinforcement in which coworkers act in a supportive manner that encourages cooperation. ${ }^{43}$ Placzek also mentions that communication within the workplace is a key factor in creating supportive networks such as a buddy system at the reference desk where coworkers can function as a tag team in a stressful situation. ${ }^{44}$ In this, librarians are being encouraged to implement a form of peer mentorship in order to create interconnectedness and support at the reference desk.

The final form of stress management illustrated throughout the literature is the implementation and continuation of strong support from upper management. Chan and Auster found that this support system in particular contributes to a positive influence on employees' job satisfaction. They argue that opportunities in professional development are not enough and that a manager should take an active interest in the professional ambitions of their staff. ${ }^{45}$ To accomplish this, Bennett recommends a number of effective communication techniques such as active listening and working lunches. ${ }^{46}$ Landry also points out that there should be close communication between staff and administration in order to maintain patron services but also to improve operating conditions for the reference librarians. ${ }^{47}$ Therefore it appears as though none of the literature calls for a lighter workload or for a retreat to the traditional methods of librarianship. Instead, it advises reference librarians who are undergoing stress in the workplace to maintain their inner sanctum through a sense of humor or hobbies outside the workplace, to reach out to others in the staff for encouragement, and to look to upper administration for guidance and support.

\section{THE FUTURE}

The recognizable premise that has been discussed throughout librarianship at its present stage has been based on the fact that librarianship is no longer a static occupation. Both Ennis and Placzek reference this fact. ${ }^{48}$ Janes points out that many people entered this profession thirty years ago for the simple reason that it was not expected to change. ${ }^{49}$ In this light, it is quite obvious why there is the potential for stress and burnout at the reference desk due to the unexpected change of pace. Although there are no current studies focused on the differences between stress levels of new librarians compared to those nearing retirement, it could be argued that librarians entering the field today are more prepared for the expectations that await them and are therefore less prone to stress. Newly graduated librarians have been taught that librarianship now requires acceptance, creativity, and ingenuity. The reason why none of the literature demands a decrease in the workload could be because the authors have recognized the current expectations of librarians and are encouraging those in this field to work toward accepting this new phase of librarianship. Although it is obvious that stress is still present, as it is in any occupation, both the stress itself and its causes have been recognized and therefore can be managed. Any individual who has future aspirations of becoming a reference librarian should be advised that this job will demand a great amount of technological skill, patience with the users, and will be increasingly time demanding for additional discrete tasks.

\section{CONCLUSION}

Reference librarians are often viewed as the face of the library. Their service to individual patrons and diverse user groups represents a great sense of responsibility toward both the patrons and the library itself. These responsibilities are based on meeting numerous expectations, and this could invariably lead to a high level of stress in a workplace that lacks a support system or a cooperative staff and manager. Because of financial restraints and legal restrictions, few libraries can provide reference librarians with the opportunity to have the time to meet user expectations fully, master and introduce new technologies, and take on an increasing number of responsibilities. Despite this, the majority of the literature also indicates that many librarians are accepting the time-bound and interruptible nature of their profession and are willing to meet the challenges that this new era of librarianship might impart. 


\section{References}

1. Les Krantz, Jobs Rated Almanac, 6th ed. (Fort Lee, N.J.: Barricade, 2002).

2. Marie B. Landry, "The Effects of Life Satisfaction and Job Satisfaction on Reference Librarians and Their Work," Reference \& User Services Quarterly 40, no. 2 (2000): 167.

3. Rockwell Schulz, James R. Greenley, and Roger Brown, "Organization, Management, and Client Effects on Staff Burnout," Journal of Health and Social Behavior 36, no. 4 (1995): 333-45.

4. Barbara Benham Tye and Lisa O'Brien, "Why Are Experienced Teachers Leaving the Profession?" Phi Delta Kappan 84, no. 1 (2002): 24-58; Steve Dinham and Catherine Scott, "Moving into the Third, Outer Domain of Teacher Satisfaction," Journal of Educational Administration 38, no. 4 (2000): 379-96.

5. John A. Collins and Philip J. Murray, "Predictors of Stress amongst Social Workers: An Empirical Study," British Journal of Social Work 26, no. 3 (1996): 375-87; Chris Lloyd, Robert King, and Lesley Chenoweth, "Social Work, Stress and Burnout: A Review," Journal of Mental Health 11, no. 3 (2002): 255-65.

6. Reference and User Services Association, "Professional Competencies for Reference and User Services Librarians," March 9, 2007, www.ala.org/ala/rusa/rusaprotools/referenceguide/professional .cfm (accessed Jan. 31, 2008).

7. Joseph Janes, Introduction to Reference Work in the Digital Age (New York: Neal-Schuman, 2003): 6-11.

8. Donna S. Bennett, "Effectively Managing the Human Side of Change," Law Library Journal 89, no. 3 (1997): 335-48; Karyle Butcher, "Reflections on Academic Librarianship," The Journal of Academic Librarianship 25, no. 5 (1999): 352.

9. Craig Brod, Technostress: The Human Cost of the Computer Revolution (Reading, Mass.: Addison-Wesley, 1984).

10. John Kupersmith, "Technostress and the Reference Librarian," Reference Services Review 20 (1992): 7-8.

11. Lisa A. Ennis, "The Evolution of Technostress," Computers in Libraries 25, no. 8 (2005): 10-12.

12. Ann Curry and Gayle J. E. Harris, "Reference Librarians' Attitudes towards the World Wide Web," Public Library Quarterly 18, no. 2 (2000): 35 .

13. John N. Berry, "Great Work, Genuine Problems," Library Journal 132, no. 6 (2007): 26-29.

14. Carol Tenopir and Lisa Ennis, "A Decade of Digital Reference," Reference \& User Services Quarterly 41, no. 3 (2002): 272.

15. Connie Van Fleet and Danny P. Wallace, "Virtual Libraries-Real Threats: Technostress and Virtual Libraries," Reference \& User Services Quarterly 42, no. 3 (2003): 188.

16. Christen Cardina and Donald Wicks, "The Changing Roles of Academic Reference Librarians over a Ten-Year Period," Reference E User Services Quarterly 44, no. 2 (2004): 133-42.

17. Sandra B. Placzek, "All in a Day's Work: What's a Reference Librarian to Do?" Legal Reference Services Quarterly 19, no. 1/2 (2001): 44.

18. Donna C. Chan and Ethel Auster, "Factors Contributing to the Professional Development of Reference Librarians," Library and Information Science Research 25, no. 3 (2003): 280.

19. Ennis, "The Evolution of Technostress," 12

20. Janes, Introduction to Reference Work in the Digital Age, 13-14.

21. Janette S. Caputo, Stress and Burnout in Library Service (Phoenix, Ariz.: Oryx, 1991): 59.

22. Placzek, "All in a Day's Work," 47; Caputo, Stress and Burnout in Library Service, 13.

23. Richard T. Sweeney, "Reinventing Library Buildings and Services for the Millennial Generation," Library Administration \& Management 19, no. 4 (2005): 168.

24. Charles Bunge, "Stress in the Library," Library Journal 112, no. 15 (1987): 49.
25. Judith Malamud and Linda Rosenstein, "Alternative Staffing at the Reference Desk," Medical Reference Services Quarterly 10, no. 3 (1991): 32.

26. Van Fleet and Wallace, "Virtual Libraries_Real Threats," 189.

27. Ennis, "The Evolution of Technostress," 11.

28. James Morris-Knower, "Reference Work in Science Libraries by Librarians Who Are Not Scientists," The Reference Librarian 34, no. 72 (2001): 155-69.

29. Fred R. Reenstjerna, "Thinking About Reference Service Paradigms and Metaphors," The Reference Librarian 34, no. 72 (2001): 155-69.

30. Cardina and Wicks, "The Changing Roles of Academic Reference Librarians," 137.

31. Tracy L. Hull and Kelley A. Lawton, "The Development of a FirstYear Student Library Instruction Program at Duke University," The Reference Librarian 35, no. 73 (2001): 323-36; Catherine Cardwell, "Faculty: An Essential Resource for Reference Librarians," The Reference Librarian 35, no. 73 (2001): 253-63; John Cruikshank and David G. Nowak, "Marketing Reference Resources and Services Through a University Outreach Program," The Reference Librarian 35, no. 73 (2001): 265-80; Sarah Reneker Andeen, "Selling the Library from the Reference Desk: Service Points as Advertisements," The Reference Librarian 35, no. 73 (2001): 281-92.

32. Placzek, "All in a Day's Work," 47

33. Butcher, "Reflections on Academic Librarianship," 351.

34. Chan and Auster, "Factors Contributing to the Professional Development of Reference Librarians," 279.

35. Placzek, "All in a Day's Work," 49.

36. Cardina and Wicks, "The Changing Roles of Academic Reference Librarians," 139.

37. Ennis, "The Evolution of Technostress," 11.

38. Placzek, "All in a Day's Work," 50.

39. Ennis, "The Evolution of Technostress," 12; Chan and Auster, "Factors Contributing to the Professional Development of Reference Librarians," 281.

40. Todd Spires, "The Busy Librarian: Prioritizing Tenure and Dealing with Stress for Academic Library Professionals," Illinois Libraries 86, no. 4 (2007): 106.

41. Landry, "The Effects of Life Satisfaction and Job Satisfaction on Reference Librarians," 174; P. Smith, "In Pursuit of Happiness: Why Study General Job Satisfaction?," in Job Satisfaction: How People Feel About Their Jobs and How It Affects Their Performance, ed. C. J. Cranny, C. Smith, and E. P. Stone (New York: Lexington, 1992): 5-19.

42. Ennis, "The Evolution of Techostress," 12.

43. Spires, "The Busy Librarian," 107; Brian Quinn, "Cooperation and Competition at the Reference Desk," The Reference Librarian 34, no. 72 (2001): 77.

44. Placzek, "All in a Day's Work," 53.

45. Chan and Auster, "Factors Contributing to the Professional Development of Reference Librarians," 279.

46. Bennett, "Effectively Managing the Human Side of Change," 342, 343.

47. Landry, "The Effects of Life Satisfaction and Job Satisfaction on Reference Librarians," 174.

48. Ennis, "The Evolution of Technostress," 12; Placzek, "All in a Day's Work," 54.

49. Janes, Introduction to Reference Work in the Digital Age, 16 